\title{
ICT Infrastructure for the Uptake of One Laptop Per Child Project in Homa Bay County, Kenya
}

\author{
Dr. Ouma Omito, \\ School of Education, Bomet University College, P.O. Box 701, Bomet, Kenya.
}

\begin{abstract}
The study was investigating the status of ICT infrastructure in preparation for the launch of Digital Literacy Programme (DLP) in public primary schools in Homa Bay County. Mixed approach research design was adopted. A total of 845 public primary schools were eligible for study. In addition, 845 public primary school head teachers and 6529 teachers were also targeted for interviews. The study randomly picked 85 schools, 6 head teachers and 12 primary school teachers for the study across the six sub counties of Homa Bay. The major findings showed that the general ICT infrastructure was low; however, majority of schools had computer laptop safes $(79.9 \%)$, electric power $(74.8 \%)$ and power sockets $(90.0 \%)$ in readiness for DLP. The study concluded that ICT infrastructures were inequitably distributed in Homa Bay County and a lot was still needed to be done for the DLP rollout to be a success. It was recommended that the government through its line ministries of ICT and energy to improve on both electric power and internet supply to make the project a reality.
\end{abstract}

Keywords: Infrastructure, Information, Communication and Technology, Digital Literacy Programme, OneLaptop-Per-Child

DOI: $10.7176 / \mathrm{JEP} / 12-32-09$

Publication date: November $30^{\text {th }} 2021$

\subsection{INTRODUCTION}

1.1 Background of the study

The One-Laptop-Per-Child (OLPC) project under the Jubilee's Digital Learning Programme in Kenya was meant, ostensibly, to entrench Information, Communication and Technology (ICT) in the teaching and learning process in primary schools (Wanzala \& Nyamai, 2018). This followed the development and enactment of ICT policy framework of the year 2006 that spelt out the measures that institutions in Kenya were to put in place to improve the general ICT infrastructures. In the policy document, the general access to computers was to improve from 150 students against one computer to an average of 15 students to one computer. The general infrastructure was also proposed in the ICT policy to improve by $80 \%$ in secondary schools and at least $10 \%$ in primary schools (Kenya. MoE, 2006). The Kenyan situation seemed to have improved greatly with the introduction of OLPC in public primary schools whereby over 19,000 public primary schools were said to have been connected to electricity and a number of computer stores were also built for all public primary schools (Kubania, 2014).

In a research conducted by IPSOS Synovate in Kenya (Kajilwa, 2017) in which a total of 2,507 people were surveyed in the whole country, it was found that despite the spirited input by the government to launch DLP in public primary schools, Kenyans felt that they needed more teachers to be employed instead of laptop computers. The research established that the government's effort to connect primary schools to electricity and distribute elearning tablets did not impress Kenyans. According to the survey, when Kenyans were asked what they thought would 'most help' improve learning conditions in primary schools, only one per cent said tablets, one percent cited provision of bursaries to needy students while some other two percent connection of schools to electric power source. Ironically, 43 per cent, which was the majority of the respondents, mentioned more or better teachers as the only cure to the country's education sector. The Synovate research showed that Kenyans still valued the input of teachers even if laptop computers were introduced.

In addition, lack of proper infrastructure for DLP in Kenya, including storage rooms was also cited as a major challenge in schools. Laptop computers were reported to have been stolen prompting schools to take these gadgets to either the chiefs' camps or police stations for safe keeping (Standard Team, 2019). Such shortages and risks in schools had not been fully solved even after the government intervened in 2005 by establishing the Kenya Education Sector Support Programme (KESSP) to outline and implement strategies that would guide infrastructure development in public primary schools (Kenya. Ministry of Education, 2005, p.1). Research data revealed that from 2003, there was still a shortfall of 43,000 classrooms countrywide, and of the ones that were there, 32 per cent were found to be below standard. It was learnt that after eight years of the launch of KESSP, the reality on the ground indicated that the infrastructures in public schools such as desks, classrooms and electricity were in short supply or non-existent in most learning institutions since some public primary schools still had classrooms that could not accommodate laptop computers simply because they were wall-less (Kubania, 2014). Furthermore, many classrooms in primary schools in Kenya lacked key facilities such as desks and were in pathetic conditions (Sharples \& Moldéus, 2014, p. 43).

Several researches in this study were in agreement that a smooth uptake of ICT in a learning institution 
needed supportive infrastructures. However, the implementers of the DLP in Kenya should be prepared for a trial and error experience based on the fact that integration of ICT in developing countries in Africa are constantly met with barriers in learning institutions which are awfully neglected and unfit for ICT integration (Shimasaki, 2015). In concurrence, Omanga (2018) argued that many public primary schools in Kenya still remained congested with learners, horrendous facilities and untrained teachers, and as such the introduction of tablets to schools was somehow insulting and needed a lot of improvement.

Homa bay County where the study was conducted was among the 47 counties in Kenya that were targeted for the DLP. The existing documents that were analyzed by the researcher showed that the county had received funds from the national government for electric power connection, training of teachers and building of laptop computer safes (Republic of Kenya, 2015). The county statistics showed that $85.8 \%$ of the public primary schools had been connected to electric power, $4 \%$ were utilizing solar power and $93.3 \%$ of them had successfully built laptop computer safes (Kenya. ICTA, 2016). However, these were just media reports that this study was out to prove.

\subsection{Statement of the Problem}

The Kenyan commitment to close the digital gaps in its public primary schools was evident in 2006 when the ICT Policy framework was developed to guide the roll out of ICT in Kenyan schools. This was followed by advocacy by the Government of Kenya in 2013. The training of teachers on ICT skills was undertaken and electricity (source of power) connected to over 19,000 public primary schools in the entire country were reported to have been done. The Government of Kenya then supplied all its public primary schools with tablets and sent some money to these schools for building safes for keeping tablets and laptops. However, the study noted that the above mentioned government commitments were just press reports. The study, therefore, was out to confirm the availability of these infrastructures in public primary schools for the support of digital learning programs in such schools.

\subsection{Purpose of the study}

The purpose of this study is to establish the level of ICT infrastructures in public primary schools for the support of digital learning programs in Homa Bay County, Kenya.

\subsection{Objective of the study}

The objective of this study is to investigate the presence of institutional ICT infrastructure in schools for uptake of laptop computers

\subsection{LITERATURE REVIEW}

ICT infrastructures as used in this research constitutes of a number of facilities that were required by public primary schools in Kenya for the uptake of laptop computer. These were: computer safes for storing of DLP devices, computer desks, sources of power, power sockets for charging laptop computers and tablets, laptop computer technical assistants, carpeted floors, internet, computer lab assistants, Uninterrupted Power Supply (UPS) for power backups and computer room policy document for guiding operations of DLP in a school.

Access to satisfactory ICT infrastructure is one of the most important factors that contribute to effective use of information technologies for teaching and learning in schools (European Commission, 2011, p.10). The absence of such infrastructures could impact negatively in the delivery of teaching and learning (UNESCO Institute for Statistics, 2015), however, the existence of up-to-date ICT resources, facilities and support in schools could be seen as a primary condition for the introduction of innovative teaching methods and use of interactive software and online materials (Mingaine, 2013). In support, Salehi and Salehi (2012) also cited insufficient technical supports at schools and little access to ICT as major barriers to ICT usage in the classroom.

The development of the ICT infrastructures in a developing country was observed to be dependent on the availability of a reliable source of power (Khan, Hasan \& Clement, 2012). In this respect, ICT integration in education which is said to be considerably more recent, small-scaled and experimental can greatly be compromised without proper infrastructure in place (Kenya. MoE, 2006). As contained in many world conventions such as Millennium Summit of the year 2000 in New York, Jomtieng Conference of 1990, among others, the right to education is the right of every citizen (UNESCO, 2009). According to these world conventions for example, the Millennium Summit of the year 2000, the world needed to aim at attaining Universal Primary Education (UPE) by 2015 (Kenya. Ministry of Education, 2005). However, ICT was believed to have the capacity to meet these world goals of Education for All (EFA) because ICT was assumed to have a positive impact on learning with benefits that embrace pupils' learning and personal development at any time anywhere (European Commission, 2011).

The use of ICTs in education, therefore, became an essential element of the educational environment. But when accompanied by technological tools and infrastructure, it would ultimately become an increasingly ever- 
present reality in society thereby expanding the base to accommodate students, teachers and educational institutions in a manner that would result in optimization of the teaching-learning process (Hernandez, 2017).

According to Mulwa, et al. (2012), 'ICT infrastructure included connectivity to various networks (internet, intranet and mobile-telephone); sources and reliability of energy (UPS, electricity, standby generators); equipment (computers, radios, videos, television, LCD projectors and software, e-learning laboratories furniture, stores and information storage facilities such as flash disks, CD-ROMs, DVDs)' ( p.24.). However, it was acknowledged that some of these modern technologies evolved from early technologies such as calculators, TV sets, and voice recorders, among others which indicated the fast evolution of technologies in the world (Hernandez, 2017).

The invention of the internet, World Wide Web (WWW), has only been in existence since 1991 and so far, it has caused the biggest change in education and learning since the advent of the printed book which is a little over 500 years ago (Draves, 2000). The internet infrastructure has had a lot of impact on educational environments such as: schools, homes, offices, libraries and complemented in a greater proportion the teaching and learning in classrooms (Clark, 2001).

In recognition of the important role technology is playing in the field of education, Chickering and Ehrmann (1996, pp. 3-6) suggested seven principles that could improve technological infrastructure and access in educational programs. They observed that learning institutions have the ability to integrate emerging technologies for either synchronous or asynchronous modes by applying the seven principles regardless of delivery, technology infrastructure and access: encourage contact between students and faculty, develop reciprocity and cooperation among students, use active learning techniques, give prompt feedback, emphasize time on task, communicate high expectations and respect diverse talents and ways of learning.

In support of the seven principles, McGrath (2006) noted that the goal of any proposed ICT infrastructure should assist the trainers to become all round teachers. That is to say, teachers should be in a position to use the right ICT resources to integrate technology in teaching and learning. DLP resources and training should be tailored to the seven principles stated above with the aim of making the integration process meaningful and productive to the school, teachers and learners in public primary schools in Kenya.

The findings of the research by the National Centre for Education and Statistics (1998) noted that discrimination was a major setback in uptake and integration in the United States of America whereby the provision of ICT infrastructures in the late 1990 's had $84 \%$ of wealthier suburban schools enjoying the internet access while only $63 \%$ of schools with high percentage of poor students were connected. The Kenyan public primary schools were operating the same way as schools in the United States of America since many urban schools in Kenya were reported to be enjoying more ICT infrastructures than rural schools despite the fact that all schools in Kenya were following a similar curriculum for teaching and learning (Kenya. Ministry of Education, 2005, p.4).

In Africa, One Laptop Per Child (OLPC) project was launched in Ghana in 2005 by a non-profit organization that was seeking to provide laptop computers to children in poorer and more remote areas of the world (Hennessy, et al., 2010). The vision of this OLPC was to allow children who had no access to quality educational opportunities to use the laptop computers to access knowledge and provide them the opportunity to manage their own learning needs regardless of their physical location or financial limitations. However, it was met with a lot of criticisms. The Ghanaians argued that it was not logical for poor nations to over spend on laptop computers at the expense of text books, libraries, teachers and other educational resources used in schools (Buchele \& Owusu-Aning, 2007).

A survey that was carried out by Eke in 2009 at the e-learning unit at University of Nigeria (Nsukka) also established that Africa was still behind in technology uptake because of poor access, networking and infrastructure. In the research, when respondents were asked about availability of computers in their places of work, 96 respondents which constituted $30 \%$ of the population indicated that there was more than one computer laboratory in their place of work, and as many as $30(9 \%)$ people claimed that there was one laptop computer available per student or worker. At the other extreme, only $20(6 \%)$ of respondents said that there were no laptop computers available where they worked, and only $14(4 \%)$ commented that there was only one computer per class available (Eke, 2011). But other studies indicated that this situation in Nigeria could be improved by governments investing heavily in technology as was noted in Australia (Gretton, Gali, \& Parham, 2002).

In Ethiopia, the government under the University Net Programme, improved the ICT infrastructures in universities and networked them to e-learning centres. In addition, schools under the School Net Programme also were networked via satellite (Reif, 2005). A similar case was witnessed in Namibia where ICT became a tool for teaching and learning in many learning institutions in both rural and urban areas (Cowan, 2005).

In 2003, a national ICT policy framework was put in place in Uganda (Hennessy, et al., 2010). The Ugandan ICT policy under strategy number two recognized the need for literacy improvement and human resource capacity building. To achieve this, Uganda rolled out ICT integration programs at all levels of education (Hennessy, et al., 2010). At primary school level, the policy aimed at encouraging schools that had 
acquired the technology to use them to support teaching, either by producing teaching materials or use them with students in the actual dissemination of content in class. To set a good foundation for the upcoming teachers, the Ugandan ICT policy was also extended to teacher-training colleges to enable newly qualified teachers to get equipped to make use of computers as it became available. It was, however, noted that ICT policy needed full implementation since many teachers and students in Uganda still lacked computers and internet. The situation was said to be even worse in the rural areas, where the majority of Ugandans (about 80 per cent) lived without electricity and connectivity to the global information network. These communities were unable to reap the numerous benefits of ICT (Hennessy et al., 2010).

\subsection{METHODOLOGY}

\subsection{Research Design}

The design adopted for this study was cross-sectional survey. Both qualitative and quantitative data were collected and then triangulated. Concurrent data triangulation works best for cross-sectional (Creswell, 2011, p.213). Survey designs have been used successfully with observation checklists and structured interviews for the generalization of findings obtained from a sample in any given study population (Cresswell, 2011, p.12). Tolmie, Muijs and McAteer (2011) added that cross sectional survey has the capacity to examine different research variables with nearly similar characteristics. In this case, the institutions under study were public schools with the main sponsor being the Government of Kenya.

\subsection{Population of the Study}

Homa Bay County had a total of 845 public primary schools. All these schools were eligible for study. In addition, 845 head teachers and 6529 teachers of these schools were eligible for interviews.

\subsection{Sampling procedure for schools}

The researcher sampled 85 out of a population of 845 schools which was $10 \%$ of the representation of the population of schools in Homa Bay County. According to Singh (2010) a sample size of between 10-20\% is reasonable and adequate in descriptive research. The sampled schools were then stratified into sub-counties of Homa Bay followed by simple random sampling based on each sub-county's numerical strength of schools and head teachers.

Table 1. Sample size of schools based on sub-counties of Homa Bay

\begin{tabular}{lcr}
\hline Sub-County & Schools & Schools \\
& N & n \\
\hline Homa Bay & 172 & 17 \\
Rachuonyo North & 167 & 17 \\
Rachuonyo South & 159 & 16 \\
Suba & 89 & 9 \\
Mbita & 109 & 11 \\
Ndhiwa & 149 & 15 \\
Total & 845 & 85 \\
& & $(10.0 \%$ of N) \\
\hline
\end{tabular}

\subsection{Sampling procedure for interview schedules}

To come up with the appropriate sample size for interviews for teachers and head teachers, populations for teachers and head teachers were separately stratified into 6 sub-counties of Homa Bay. The same teachers' population of 6529 and the head teacher' populations of 845 in Homa Bay County were used to come up with the sample size for interview schedules.

In each sub-county, the study randomly picked one head teacher and two teachers for an interview. The teachers and head teachers were picked randomly for the interviews regardless of whether they had undergone DLP training or not. This was because all teachers in public primary schools were expected to be ready for DLP. Interviews were to help in data triangulation and resolve unclear information on the area of research that could not be gleaned from the observation schedules, thus filling in the gaps and strengthening the information in the study. According to Mason (2010) the number of participants that should be interviewed for a PhD case study should range between 1 and 95 .

\subsection{Research instruments}

Data was gathered in two ways. Observation checklist was used to generate data on ICT infrastructure. Both teachers and head teachers were also interviewed by the researcher using interview schedules.

\subsubsection{Observation checklist on schools' ICT infrastructure}

The observation checklist was important for this research because the study needed to verify the availability or 
absence of the required ICT facilities and infrastructures that were necessary for the uptake of laptop computers in schools. The checklist enabled the researcher or research assistant to make his or her own observations and make recordings without misinformation as sometimes witnessed in many dishonest respondents, particularly for questionnaires and interview schedules, who would deliberately give false or inaccurate information (KIM, 2009). In this case, the researcher or research assistants were able to get detailed information on the required ICT infrastructures of each of the sample schools.

The researcher or research assistants observed ICT infrastructure such as availability of computer storage facility, computer room chairs, power generator, power sockets, laptop computer technical assistant, internet, solar power, carpeted floors, electric power, uninterrupted power supply, laptop computer classroom laboratory attendant and laptop computer room policy document. The researcher or research assistants recorded the observations using a checklist. The head teacher being the overall leader and the key gatekeeper of the school assisted the researcher or research assistants in making such observations.

\subsection{Reliability and validity of research instruments}

Reliability tests on the ability of the research instruments to produce dependable results over a given period of time. Validity on the other hand aims demonstrates the accuracy of the research instruments to measure accurately what is expected to measure. The instruments (observation checklist and interview schedule) were found to have captured the key areas of study and hence were found to be valid. This was done by relevant experts who had adequate knowledge in the subject area. Cronbach's alpha $(\alpha)$ was used to determine the reliability coefficient of piloting data obtained from observation checklist on ICT infrastructure. A reliability coefficient value of 0.71 was obtained which the researcher regarded as adequate. Statistical Package for Social Sciences (SPSS) was used to generate this data.

\subsection{Data Collection Procedures}

To ensure full compliance with the code of ethics governing research, a research permit was issued by National Commission for Science and Technology Innovation (NACOSTI). The Ministry of Education in Kenya and the County Commissioner of Homa Bay forwarded the same. County Commissioner assured the researcher and the research assistants of their security while the Ministry of Education sensitized the respondents and schools of the research activity. Because the area of study was wide, both the researcher and the research assistants participated in the study. The collected data were then treated to ensure accuracy. The data from the observation checklist was keyed in for data analysis using SPSS. Qualitative data from the interviews was also prepared for analysis by transcription and coding..

\subsection{Data Analysis}

Quantitative data was analysed using SPSS and data presented in tables, percentages and average mean scores. Qualitative data from the interview schedules was analysed by transcription, coding and finally organizing them into major thematic areas. Reporting was finally done both in verbatim and in percentages.

\subsection{RESEARCH FINDINGS}

\subsection{Response rate}

The response rate for ICT infrastructures was $100 \%$. Interviews were also successfully conducted with all sample respondents resulting in $100 \%$.

\subsection{General ICT infrastructures in sampled primary schools}

To establish the position of public primary schools in terms of the necessary ICT infrastructures, a total of 85 sample schools which were stratified into six sub-counties of Homa Bay were observed. The ICT Infrastructures for laptop computers in this study comprised of the necessary facilities that the public primary schools under this research required for the launch and smooth usage of laptop computers for teaching and learning in schools. The study explored the availability of a number of facilities that were considered by the research as necessary for the uptake of laptop computers as expressed in objective one of this study. These were the availability of: computer safes, computer room chairs/desks, carpeted floors, internet, power sockets, laptop computer technical assistants, power generators, electric power, solar power, Uninterrupted Power Supply (UPS), computer laboratory attendants and computer room policy documents. The researcher or research assistants made direct observations and recorded availability or non-availability of the aforementioned ICT infrastructures in the sample schools. 
Table 2. General ICT infrastructures in sampled primary schools

\begin{tabular}{lcr}
\hline ICT Infrastructure & Available & Percent \\
\hline Laptop computer safes & 68 & 79.9 \\
Computer room chairs & 11 & 13.1 \\
Carpeted floors & 2 & 2.1 \\
Internet & 15 & 18.0 \\
Power sockets & 77 & 90.0 \\
Laptop computer technician & 14 & 17.6 \\
Electric power & 63 & 74.8 \\
Power generators & 5 & 5.6 \\
Solar power & 6 & 7.2 \\
Uninterrupted power supply (UPS) & 5 & 5.7 \\
Laptop computer room attendant & 19 & 22.0 \\
ICT policy document & 19 & 22.0 \\
Average & & 29.8 \\
\hline
\end{tabular}

The findings from Table 2 showed that 68 (79.9\%) sample schools which were observed had at least a structure either built on the classroom wall or metallic box that they called laptop computer safes/store in their schools. $17(20.1 \%)$ schools out of the 85 sample schools in the study had no laptop computer safes anywhere within their school compound.

When the researcher observed whether the designated DLP classrooms had appropriate chairs and desks for laptop computers, $11(13.1 \%)$ sample schools had either made or purchased the required computer desks and chairs.74 (86.9\%) sample schools still lacked appropriate furniture for handling laptop computers and tablets in their classrooms.

The nature of floors for the designated DLP classroom was observed to establish whether the classroom floors were carpeted to create dust free and safe environments for computer laptops and tablets. It was established that only $2(2.1 \%)$ sample schools had their classroom floors carpeted. The majority of the sample schools, $83(97.9 \%)$, had no carpeted classroom floors.

Internet was a requirement for soft copy content display and delivery to learners by laptop computers. It was observed that $70(72.0 \%)$ sample schools had no access to internet for teaching and learning. 15 (18.0\%) sample schools which already had received DLP devices, and particularly, wireless routers which had no internet service provider and, therefore, could not access the internet as was expected.

Laptop computers needed a source of power for running its programs. The sample schools observed indicated that $63(74.8 \%)$ out of 85 sample schools had functional electric power, while $22(25.2 \%)$ had no source of electric power. Only $5(5.6 \%)$ sample schools observed had power generators as an alternative power supply in case of electric power blackout. The rest of the sample schools, $80(94.4 \%)$, had no power backup generators. 6 (7.2 \%) sample schools had solar power. A high number of sample schools, $79(92.8 \%)$, had no solar panels as either the main source of power or an alternative source of power for the schools during power blackouts. But when the researcher observed the power installation systems in DLP classrooms, it was established that $77(90.0 \%)$ sample schools had power sockets on the walls of the designated laptop computer classrooms. $8(10.0 \%)$ sample schools had no power sockets placed anywhere on the walls of their designated laptop computer classrooms.

Uninterrupted Power Supply (UPS) was equally treated by this study as an alternative power source that could either be used to charge laptop computers or connect directly to laptop computers when either the laptop computer battery was faulty or during power blackouts. It was found that $5(5.7 \%)$ sample schools, which had desktop computers before had UPSs. The remaining $80(94.3 \%)$ sample schools had no UPSs.

For maintenance and repair of laptop computers, technical support either in school or at the county level was needed. The findings showed that $14(17.6 \%)$ sample schools had some people they believed could offer technical support informally. The remaining 71 (82.4\%) sample schools did not know what to do with damaged and malfunctioning laptop computers.

As well, designated laptop computer classrooms needed somebody either employed by the school or government to look at the cleanliness of the classroom and safety of laptop computers in the school. It was observed that $19(22.0 \%)$ sample schools had identified laptop computer classroom attendants. The majority of the sample schools, $66(78.0 \%)$, had no idea of the necessity of computer classroom attendants.

Computer policy document was considered by the study as a requirement for any institution engaging in elearning. As part of ICT infrastructure, computer room policy document could specify the day- to- day operations in a computer room. It could also outline the responsibilities of each personnel in an e-learning environment. It was observed that $19(22.0 \%)$ sample schools had some written guidelines which they considered as ICT policies while $66(78.0 \%)$ which were the majority had no idea of ICT policies in their 
schools.

\subsection{Institutional Information, Communication and Technology infrastructures in sub-counties}

To further establish equity in distribution of the necessary ICT infrastructures, the study investigated the availability of ICT infrastructures in each six sub-counties of Homa Bay County which were under study. The six sub-counties were: Homa Bay, Mbita, Rachuonyo North, Rachuonyo South, Suba and Ndhiwa. The results were tabulated as shown in Table 3.

Table 3. ICT infrastructures in sub-counties

\begin{tabular}{|c|c|c|c|c|c|c|c|}
\hline Sub-Counties & Homa Bay & Mbita & R. North & $\begin{array}{l}\text { R. } \\
\text { South }\end{array}$ & Suba & Ndhiwa & Average \\
\hline ICT infrastructure & $\%$ & $\%$ & $\%$ & $\%$ & $\%$ & $\%$ & $\%$ \\
\hline Laptop computer safes & 94.1 & 90.9 & 76.5 & 68.8 & 88.9 & 60.0 & 79.9 \\
\hline Computer room chairs & 29.4 & 18.2 & 11.8 & 12.5 & 0.0 & 6.7 & 13.1 \\
\hline Carpeted floors & 0.0 & 0.0 & 0.0 & 12.5 & 0.0 & 0.0 & 2.1 \\
\hline Internet & 11.8 & 27.3 & 5.9 & 18.8 & 44.4 & 0.0 & 18.0 \\
\hline Power sockets & 88.2 & 81.8 & 100.0 & 87.5 & 88.9 & 93.3 & 90.0 \\
\hline Laptop computer technician & 0.0 & 18.2 & 17.6 & 25.0 & 44.4 & 0.0 & 17.6 \\
\hline Electric power & 94.1 & 81.8 & 94.1 & 87.5 & 44.4 & 46.7 & 74.8 \\
\hline Power generators & 5.9 & 9.1 & 5.9 & 12.5 & 0.0 & 0.0 & 5.6 \\
\hline Solar power & 11.8 & 9.1 & 0.0 & 0.0 & 22.2 & 0.0 & 7.2 \\
\hline Uninterrupted power supply (UPS) & 0.0 & 27.3 & 0.0 & 0.0 & 0.0 & 6.7 & 5.7 \\
\hline Laptop computer room attendant & 0.0 & 45.5 & 29.4 & 12.5 & 44.4 & 0.0 & 22.0 \\
\hline ICT policy document & 5.9 & 45.5 & 29.4 & 0.0 & 44.4 & 6.7 & 22.0 \\
\hline Average & 28.4 & 37.9 & 30.9 & 28.1 & 35.2 & 18.3 & 29.8 \\
\hline
\end{tabular}

The findings from Table 3 showed that $94.1 \%$ sample schools in Homa Bay Sub-County, 90.9\% in Mbita Sub-County, 76.5\% in Rachuonyo North Sub-County, 68.8\% in Rachuonyo South Sub-County, 88.9\% of the sample schools in Suba Sub-County and $60.0 \%$ of the sample schools in Ndhiwa Sub-County had laptop computer safes or stores either built on the classroom walls or had a separately built metallic safe within the school compound. Based on the findings, Homa Bay Sub-County had the highest number of computer safes or stores available for laptop computer storage.

The study also observed the existence of suitable chairs and desks that could be used by learners to rest their tablets. $29.4 \%$ of sample schools in Homa Bay, $18.2 \%$ of sample schools in Mbita, $11.8 \%$ of sample schools in Rachuonyo North, $12.5 \%$ of sample schools in Rachuonyo South, no sample school in Suba and $6.7 \%$ of sample schools in Ndhiwa had appropriate desks or tables to use for teaching and learning using laptop computers. The findings revealed that most schools in the entire county registered very low commitment to desks and tables for uptake of laptop computers in public primary schools in Homa Bay County.

The nature of the classroom floors that were expected to host laptop computers was also observed. For computers to function properly, they had to be in a dust free environment. Dust interferes with key pads and circulation of air in and out of the digital devices. Any blockage of air circulation would interfere with the safety of laptop computers. It was observed that the floors of all the sample schools that were sampled in the six subcounties were not carpeted apart from a small percentage $(12.5 \%)$ of the sample schools in Rachuonyo South Sub-County.

The availability of internet in all public schools in Homa Bay County was regarded by the study as important for content transmission and research by teachers and learners. It was realized that $11.8 \%$ of the sample schools in Homa Bay, $27.3 \%$ of sample schools in Mbita, $5.9 \%$ of sample schools in Rachuonyo North, $18.8 \%$ of sample schools in Rachuonyo South, $44.4 \%$ of sample schools in Suba and no sample school in Ndhiwa had no source of internet connection.

Power sockets were necessary for charging laptop computers and tablets. It was revealed that $88.2 \%$ of sample schools in Homa Bay, $81.8 \%$ of sample schools in Mbita, all sample schools in Rachuonyo North (100.0\%), 87.5\% of sample schools in Rachuonyo South, $88.9 \%$ sample schools in Suba and $93.3 \%$ of sample schools in Ndhiwa had power sockets.

According to the study, each sample school studied needed a technician to take care of laptop computers and tablets' breakages or difficulties in operations. The study showed that the sample schools in Homa Bay and Ndhiwa sub-counties had nobody in mind that they could refer to incase of breakages or faults in laptop computers and tablets. $18.2 \%$ of sample schools in Mbita, $17.6 \%$ of sample schools in Rachuonyo North, $25 \%$ of sample schools in Rachuonyo South and $44.4 \%$ of the sample schools in Suba had identified some people they could rely on when the devices were faulty. 
The requirement for any device that uses electricity to function is the source of power. It was established that $94.1 \%$ of sample schools in Homa Bay Sub-County, $81.8 \%$ of sample schools in Mbita Sub-County, 94.1\% of sample schools in Rachuonyo North Sub-County, 87.5\% of sample schools in Rachuonyo South Sub-County, $44.4 \%$ of sample schools in Suba Sub-County and $46.7 \%$ of sample schools in Ndhiwa Sub-County had electricity generated by Kenya Power and Lighting Company. The findings noted that there was still an averagely low supply of electricity in both Suba and Ndhiwa sub-counties to sample schools.

Apart from the electric power mentioned above, some other power backups were needed especially when electric power was not there. It was revealed that only $5.9 \%$ of the sample schools in Homa Bay , 9.1\% sample schools in Mbita ,5.9\% sample schools in Rachuonyo North and 12.5\% sample schools in Rachuonyo South had power generators to use in case of prolonged power blackouts. Alternatively schools also needed to be equipped with solar panels to use either directly during the learning process or when there were power blackouts. The study found that $11.8 \%$ of sample schools in Homa Bay, $9.1 \%$ of sample schools in Mbita and $22.2 \%$ of sample schools in Suba had solar panels. The sample schools in the rest of the sub-counties of Homa Bay had no solar power.

Uninterrupted Power Supply (UPS) were necessary to cushion against abrupt power interruption especially when the laptop computer and tablet batteries were either low or not working. $27.3 \%$ of sample schools in Mbita and $6.7 \%$ of Suba had UPS. These sample schools with UPS had desktop computers in their schools. The rest of the sample schools in the remaining sub-counties had no UPS.

Apart from the teachers in school, a support staff in charge of laptop computers and tablets was a requirement according to this study. It was established that sample schools in two sub-counties of Homa Bay and Ndhiwa had no idea on the need to have a support staff for DLP. However, $45.5 \%$ of sample schools in Mbita, $29.4 \%$ of sample schools in Rachuonyo North, $12.5 \%$ of sample schools in Rachuonyo South and $44.4 \%$ of sample schools in Suba referred to their teachers as the classroom attendants for laptop computers in school. No sample school in all the sub-counties had specifically employed attendants for laptop computers in their schools. Finally, a document that could give direction on handling, repair and general usage of laptop computers and tablets needed to be available in each sample school. The study found that 5.9\% of sample schools in Homa Bay, $45.5 \%$ of sample schools in Mbita, $29.4 \%$ of sample schools in Rachuonyo North, $44.4 \%$ of sample schools in Suba and $6.7 \%$ of sample schools in Ndhiwa had some guidelines on the handling of DLP devices.

\subsection{Discussion}

The general ICT infrastructures in public primary schools in Homa Bay County stood at 29.8\% which this study considered to be low and needed to be improved. The research findings on ICT infrastructures in public primary schools in Homa Bay County showed that each sample public primary school in Homa Bay County had the knowledge of some ICT infrastructures required to support the paradigm shift in teaching and learning that involved the use of electronic devices. That is to say, respondents were aware of the Government of Kenya's initiative to migrate from hard copy books to digital learning platforms. But contrary to the expectations of the ICT Authority of Kenya that before DLP integration, each DLP school should have source of electricity, secure storage cabinets, flat surface desks, burglar proof doors and windows dust proof floors (Kenya. DLP Secretariat, 2016, pp. 9-10), the research findings revealed that the government selectively funded laptop computer storage facilities, electric power and installation power sockets in public primary schools and ignored other ICT infrastructural areas. The general ICT infrastructures for DLP remained inadequate in most sampled public schools in Homa Bay County. The findings were in line with European Commission (2011) revelation that access to ICT infrastructure was core to the establishment of any ICT program and the absence of such infrastructures could negatively impact the delivery of teaching and learning in an institution.

To further triangulate data on ICT infrastructures in these sample schools, the study conducted oral interviews with a total of 6 head teachers and 12 assistant teachers in Homa Bay County with the main question asking for the adequacy of ICT infrastructures in their respective public primary schools. In their response, 18 $(100 \%)$ respondents were in concurrence with the outcome of the observation checklist that there were inadequate ICT infrastructures in their respective schools. These research findings were also in line with Khan et al. (2012) who observed that lack of ICT resources is a major threat to the growth of ICT in the developing countries like Kenya. The study interviews also confirmed that the Government of Kenya was in touch with all public primary schools as far as laptop computer uptake was concerned. For example, the $18(100 \%)$, sample respondents who were interviewed agreed to have some knowledge on the basic ICT infrastructures that were necessary for the uptake of laptop computers in schools such as a steady source of power for the digital equipment such as laptop computers.

Many sample schools that were observed by this study had at least a structure they were referring to as laptop computer safes in their schools. This was confirmation of the report issued by the Government of Kenya that all public primary schools in Kenya had been allocated Kshs. 1.27 Million (\$ 14,111USD) for storage facilities (Republic of Kenya, 2015). It was true that the government disbursed funds to public primary schools 
to build storage facilities for DLP devices. However, the money which was disbursed to schools was not enough for storage facilities and installation of electricity in DLP classrooms in many sample public primary schools in Homa Bay County thereby leaving 18 (21.1\%) sample schools in the county unable to account for the funds since their schools had no storage facilities. Lack of storage facilities in some sample schools could also be linked to embezzlement of public funds by head teachers since the government did not provide an alternative list of schools that did not receive such funds in the country. When the study compared its findings of $79.9 \%$ availability of computer safes to that of ICT Authority (2016), 93.3\%, and did not give any report whether the DLP classrooms had power sockets on the wall or not. The study observed that sample public primary schools in Homa Bay County were ready for DLP in terms of storage facilities for DLP devices.

However, it also came to the attention of the study that a number of storage facilities were incomplete and unsafe for use at the time of the study and posted a lot of security risks in primary schools (Kenya. ICTA, 2016, Standard Team, 2019). To confirm this, there were calls from all directions for teachers to improve on the security of DLP devices in their schools (Muriuki, 2017; Buchele, et al., 2007). The calls to secure schools for DLP was supported by ICT Authority in Homa Bay County which in its report had received six thefts and three attempted thefts reports from different schools in Homa Bay County. The study noted that there were difficulties of securing DLP devices because the situations of the classrooms where DLP devices were to be kept in many schools were pathetic and indeed some of these classrooms were wall-less (Kubania, 2014). On the other hand, there was completely no uniformity in the way laptop storage facilities were built and distributed in schools sampled. According to the Kenyan DLP Secretariat (2016), a secure storage cabinet should have had sufficient number of power sockets and power strips to charge devices. The storage cabinet should have been either metallic or concrete with burglar proof doors.

The specifications for building storage cabinets were never followed since each school was allocated money without adequate information on construction. The outcome of such construction was that schools ended up constructing safes of their own designs. The only common thing that most schools observed was that the safes were built in designated rooms for standard one learners, a position that was refuted by ICT Authority in Homa Bay County in its report. The ICT Authority in Homa Bay County maintained that schools only needed an ICT room and not a classroom. Nevertheless, teachers' recognition of ICT rollout in schools proved that teachers were expected to be facilitators of DLP (National Centre for Education Statistics, 1998; Republic of Kenya, 2015; Sharples \& Moldéus, 2014).

Some sub-counties registered higher percentages of installation of power sockets than others. Although the research findings were in concurrence with the ICT Authority of Homa Bay County that most schools had power sockets, their statistics differed slightly. That is, the ICT Authority of Homa Bay County recorded no information on power socket installations while the government at the national level indicated that all schools had complete wiring done (Republic of Kenya, 2015). However, the study findings only registered 77 (90. 0\%) sockets in all sample schools. It was not very clear to the study why $8(10.0 \%)$ schools that were sampled were still lacking power sockets, yet the government had disbursed funds for the same to all public schools in the Republic of Kenya (Republic of Kenya, 2015).

The study also found that classrooms that were set to receive laptop computers and tablets did not have appropriate chairs and tables for laptop computers. The study observed that $86.9 \%$ sample schools had no properly designed laptop computer desks but the ones that were there were dilapidated and, in most cases, had more pupils than their seating capacity in many sample schools that had high population of pupils. These desks had tops that were narrow and not steady to host tablets for each pupil. Apart from being uncomfortable, laptop computers and tablets risked slipping and falling down on the floors during the learning process. The poor state of classrooms was in line with findings of Sharples and Moldéus (2014), Kubania (2014) and Omanga (2018) who noted that the state of infrastructures in public primary schools in Kenya were not conducive for DLP. The standard desks or tables used in class should have had flat surfaces (Kenya. DLP Secretariat, 2016, p.10). The majority of schools in all sub-counties of Homa Bay County registered fewer numbers of appropriate desks and tables for teaching and learning using laptop computers and tablets. The sub-county of Suba was hard hit as no sample school had appropriate desks or tables for laptop computers and tablets. The main reason mentioned by the respondents of Suba during the interview session was the inability of most public primary schools to buy or make the right furniture for laptop computers and tablets on their own. Lack of appropriate desks and chairs could grossly affect the uptake of laptop computers in Homa Bay County because many people view school infrastructural development as an activity that has been left in the hands of poor parents and communities and as such, public primary schools lacked classrooms to accommodate learners leave a lone desks and tables for DLP (Kubania, 2014)

In connection to classroom desks, the study revealed that only $2(2.1 \%)$ schools in the county which were in Rachuonyo South Sub-County had the designated DLP classrooms carpeted. The rest of the sample schools in the remaining sub-counties of Homa Bay had no carpets on their floors at the time of the study. This was observed by the study as a threat to the life span of the laptop computers and tablets as dust from classroom 
floors could easily accumulate and cause overheating of laptop computers due to shortage of air circulation. It was noted by the study that a good number of classroom floors were cemented but still were dusty to host laptop computers and tablets. The carpeted floors were needed to provide cover for dusts and prevent breakages of tablets in case they slip and fall on the floor. The life span of laptop computers was also greatly compromised in a dusty environment. In support KESSP research data revealed that from 2003, Kenya still had a shortfall of 43,000 classrooms countrywide, and of the ones that were there, $32 \%$ were found to be below standard (Kenya. Ministry of Education, 2005, p.1).

$63(74.8 \%)$, which was the majority of the sample schools under study, had functional electric power. However, the study established that some of the remaining sample public primary schools without functioning electricity had power lines and electricity transformers at a close range for tapping. The outcome of the study proved that indeed the government had invested a lot of money for the provision of electricity to all public schools. The research outcome was in concurrence with the Government of Kenya's declaration that over 19,000 schools had been connected to the national power grid by 2015 (Republic of Kenya, 2015). The power connection statistics were further confirmed by comparing the nationwide connection as reported by the Government of Kenya 19000 (84.4 \%) schools (Republic of Kenya, 2015), ICT Authority Homa Bay County $725(85.8 \%)$ schools (Kenya. ICTA, 2016) and the study's findings that stood at $63(74.8 \%)$.

However, there appeared also to be disparities in power distribution among the sub-counties of Homa Bay. For instance, Homa Bay and Rachuonyo North sub-counties had the highest number of connections at $94.1 \%$ each while Suba and Ndhiwa sub-counties registered the least connections at $44.4 \%$ and $46.7 \%$ respectively of the schools. This report is in complete disagreement with the Government of Kenya report which showed that power connections in Suba stood at $78.4 \%$ ( Kenya. ICTA, 2016). The disparity agrees with the findings of National Centre for Education and Statistics (1998) revelation that there was discrimination in the provision of ICT infrastructure in the late 1990's where wealthier suburban schools enjoyed more facilities than poor schools in the United States of America.

The findings from interview schedules found that $12(66.7 \%)$ respondents had electricity in their schools. Interestingly, Suba which had the least electric power connections had the highest number of solar power connections at $22.0 \%$ which was ahead of all other sub-counties of Homa Bay. The findings which were confirmed by ICT Authority of Homa Bay that had also put solar distribution in Suba at $16 \%$ which was higher than the rest of the sub-counties in Homa Bay. The inequitable distribution of power in Kenya was linked to the Rural Electrification Program that seemed to have also stratified regions in such a way that some regions were served ahead of others. In terms of laptop computer program, it meant that schools with the required infrastructures such as steady source(s) of power were well ahead of others in uptake of e-learning ( Hennessy et al., 2010; Hermandez, 2017; Kubania, 2014; Mulwa et al., 2012).

The availability of UPSs and power generators were found by the study to be very few across all the subcounties of Homa Bay. The study observed that the stakeholders and the government underrated the role of power backups in a system that had unsteady supply of power (Mulwa et al., 2012). Although laptop computers and tablets had batteries that could take a minimum of 6 hours and a maximum of 30 hours, learning could severely be affected when the power blackouts took more than two days (Kenya. ICTA, 2016). In addition, other DLP devices such as projectors had no batteries and depended wholly on external power sources. A steady source of power was needed for any digital device to function optimally for the benefit of teaching and learning (Hannessy et al., 2010). But the participants and implementers of e-learning needed not over trust one source of power because there could be power surges or technical hitches in power system without notice (Khan et al., 2012). The UPS and power generators as alternative sources of power could be used to charge laptop computer batteries as well used directly during teaching and learning. The researcher noted no disparities in terms of availability of UPS and generators in sub-counties of Homa Bay since all the sub-counties registered very few cases of generators and UPS in schools.

Content delivery from KICD to learners through the use of Learner Digital Device (LDD) and Teacher Digital Device (TDD) could either be offline or online (Kenya. DLP Secretariat, 2016). The availability of internet and intranet in all public primary schools in Kenya was, therefore, a requirement to support online education. This is because schools needed not to visit KICD physically for content for DLP. Also, teachers by use of browsers could source for additional teaching materials by use of the internet (Kenya. DLP Secretariat, 2016, pp. 19-20). However, the study only established that only a few schools in 5 sub-counties of Homa Bay County that had received the digital learning devices had been given inactive routers that could connect them to KICD for the digital content deployment. No internet service providers were available to be used by such routers. In addition, teachers appeared not to have adequate expertise in configuration of the servers to TDD and LDD because it needed advanced ICT skills (Kenya. DLP Secretariat, 2016, p.21). The provided DLP servers could only provide stored digital content from KICD instead of internet. Sample schools in Suba Sub-County showed no presence of such servers and routers simply because ICT Authority in Kenya was distributing these devices in phases. Internet was expected to expand the knowledge base of the teachers and learners by directly sourcing 
information from KICD and World Wide Web (WWW). In support, European Commission (2011) argued that modern education in class was beyond the use of computers alone. Both teachers and students needed to make good use of WWW. Mulwa et al. (2012) added that an organization should be ready for an online education by putting in place both intranet and internet. To further prove the impact of internet in teaching and learning, ICT Authority of Kenya demanded that teachers needed to either get digital contents directly from KICD or develop their own contents for usage using the DLP devices. And because internet was not available in $70(82.0 \%)$ sample schools under study, readiness for the integration of DLP was greatly compromised. This was in line with Clark (2001) who observed that internet technology has shown a lot of impacts in an educational environment.

A computing environment should at least have somebody with know how to assist teachers and pupils when there is a breakdown or programming of the operating systems apart from simple provision of computer tutorials. The research revealed that all sample schools in both Homa Bay and Ndhiwa sub-counties had nobody in mind that they could refer to as either laptop computer assistant or technician. The remaining sub-counties registered very low percentages, but the people they were relying on as either technicians or laptop computer room attendants were simply teachers within their schools. This was dangerous to the uptake of laptop computers because faults and breakages of DLP devices could interfere with smooth learning (Wanzala \& Nyamai, 2018). Technicians and ICT support staff were necessary in situations where teachers were not sure of connecting laptop computers to the tablets, servers and the projector. This is because connections of DLP devices needed advanced computer skills (Kenya. DLP Secretariat, 2016). In support, European Commission (2011) also noted that there is no meaningful e-learning without proper technical support.

In recognition of the role of technical staff, ICT Authority of Kenya gave contacts of Moi University, Jomo Kenyatta University and ICT Authority of Kenya as support contacts which actually were too far from subcounties under study (Kenya. ICTA, 2016). In addition, the respondents were not advised accordingly on these contact organizations and had no specific contacts in case of challenges (Standard Team, 2019). The same statement was echoed by a teacher who was interviewed and said:

And then we have machines which are going to breakdown, so far, nobody has told us how they are going to be replaced or is it that the individual said we are going to stay that way if the machine breaks...(Teacher, Mbita).

Computer room policy document was considered by this study as a key infrastructural document both at the national and school level. Such a crucial policy document was expected to define the management and functionality of digital devices in institutions. When the researcher/research assistants visited the sample schools for observations, $66(78.0 \%)$ schools had no knowledge of any ICT policy documents. That means, the ICT policy documents both from the national level to school level were not available in schools to give directions. McGrath (2006) supported by saying that policy guidelines must not be ignored because they raise a number of questions that need to be answered in an e-learning organization such as: Who will coordinate these programs? Who will monitor or enforce participation?

A few schools that claimed to have the ICT policy document showed some rudimentary documentation especially in their staff minutes book indicating the names of teachers in their schools who were allocated duties to be in charge of DLP in their schools. On the other hand, it was possible that some schools without the prior knowledge of the necessity of an ICT policy document could uptake and integrate laptop computers in their institutions without the ICT policy document in place. Without such a crucial document, the entire Digital Literacy Programme (DLP) could be messy based on the fact that institutions could not successfully work without regulations governing such issues as: how to procure, how to use, how to store and how to repair digital devices, among others (European Commission, 2011). In support, the Ministry of Education in Kenya in the year 2006 came up with an ICT policy document that laid the foundation for DLP and other ICT initiated projects in Kenya like the Nepad e-schools. In addition, East African countries had also developed their own ICT policy documents (Kenya. MoE, 2006; Hennessy et al., 2010). In South Africa, for example, Plessis and Webb (2012) attributed low uptake of e-learning to the apartheid policy prior to 1994 that discriminated Africans.

\subsection{Conclusion and recommendation}

It was concluded that the Government of Kenya scored highly in connecting majority of primary schools in Kenya to a reliable electric power. Power as a source of energy played a key role in the implementation of DLP in public primary schools in Homa Bay County. However, the study noted that a clear policy guideline for the roll-out of DLP was missing. The schools did not have an idea on who exactly to consult incase breakages or malfunctions of DLP devices because the three government agencies such as the Ministry of Education, Teachers Service Commission and ICT Authority of Kenya had no distinct roles to play in the implementation process. The study also noted inequitable distribution of ICT infrastructures across the six sub counties of Homa Bay. It was recommended that the Government of Kenya through its ministries of ICT and energy to improve on both power and internet infrastructure in order to make the implementation of the project a reality. 


\section{REFERENCES}

Buchele, S. F., \& Owusu-Aning, R. (2007). The one laptop per child (OLPC) project and its applicability to Ghana. In Proceedings of the 2007 International Conference on Adaptive Science and Technology, pp. 113118 .

Chickering, A., \& Ehrmann, S. E. (1996). Implementing the seven principles: Technology as lever (Electronic version). American Association for Higher Education, 3-6. Retrieved from American Academics and Higher Education website: http://www.tltgroup.org/programs/seven/

Clark ,M. (2001). The soft technology of distance education. Retrieved from University of Cincinnati website: http://www.uc.edu/ucitnow/summer_ol/softtech.html

Cowman, J. (2005). Global perspectives on e-learning. British Journal of Educational Technology, 36 (4), 693694.

Creswell, J.W. (2011). Research design. Qualitative, quantitative, and mixed methods approaches (3 ${ }^{\text {rd Ed.). }}$ Boston: Pearson Education, Inc.

Draves, W. A. (2000). Teaching online. River Falls, NJ: LERN Books.

Eke,H.N. (2011). Modeling LIS students' intention to adopt e-learning: A case from University of Nigeria, Nsukka.

from: http://digitalcommons.unl.edu/cgi/viewcontent.cgi?article=1496\& context=libphilprac

European Commission. (2011). Key data on learning and innovation through ICT at school in Europe. Brussels: Education, Audiovisual and Culture Executive Agency. Retrieved from: https://www.cseeetuce.org/images/attachments/ictkeydata_on_learning_and_innovation_through_ict_2011_ summary.pdf

Gretton, P., Gali, J., \& Parham, D. (2002, December). Uptake and impacts of ICTs in the Australian economy: Evidence from aggregate, sectoral and firm levels. Paper prepared for the Workshop on ICT and Business Performance OECD, Paris. Retrieve from: https://www.pc.gov.au/research/supporting/ict-uptake/uiict.pdf

Hennessy,S., Harrison,D., Ang'odi,E.K., Nemalefe,S., Naseem,A., \& Wamakote,L. (2010). Developing the use of information and communication technology to enhance teaching and learning in east African schools: Review of the literature. Eastern Africa: Centre for Commonwealth Education and Aga Khan University Institute for Educational Development.

Hernandez, R.M. (2017). Impact of ICT on education: Challenges and perspectives. A manuscript presented for publication Retrieved from: http://dx.doi.org/10.20511/pyr2017.v5n1.149

Kajilwa, G. (2017, February 6). Survey: Kenyans want more teachers, not free laptops. Standard Digital. Retrieved from: https://www.standardmedia.co.ke/article/2001228495/survey-kenyans-want-more-teachersnot-free-laptops

Khan, S. H., Hasan,M., \& Clement, C.K. (2012). Barriers to the introduction of ICT into education in developing countries: The example of Bangladesh. International Journal of Instruction, 5(2). Retrieved from: www.eiji.net

Kenya. DLP Secretariat. (2016). Digital literacy programme management guidelines (2 ${ }^{\text {nd }}$ Version).Nairobi: Information Communication and Technology Authority.

Kenya. ICTA (2016). Homa Bay Digital Literacy Report. Homa Bay County: ICT Authority

Kenya. Ministry of Education (2005). Kenya Education Sector Support Programme 2005 - 2010. Nairobi: Ministry of Education

Kenya. MoE (2006). National ICT strategy for Education and Training. Nairobi: Ministry of Education

KIM (2009). Fundamentals of management research methods. Nairobi: Macmillan Publishers Limited.

Kubania, J. (2014, March 19). Sorry state of infrastructure in Kenya's primary schools. Daily Nation. Retrieved from: $\quad$ https://www.nation.co.ke/lifestyle/dn2/Sorry-state-of-infrastructure-in-Kenyas-primaryschools/957860-2249632-13jxnc4z/index.html

Mason, M. (2010). Sample size and saturation in PhD studies using qualitative interviews. Forum Qualitative Sozialforschung / Forum: Qualitative Social Research, 11 (3). Retrieved from: http://www.qualitativeresearch.net/index.php/fqs/article/view/1428/3027

McGrath, L. (2006). Developing e-learning policies at the department level. MERLOT Journal of Online Learning and Teaching, 2, (3), 177-186.

Mingaine, L. (2013). Skill challenges in adoption and use of ICT in public secondary schools, Kenya. International Journal of Humanities and Social Science, 3 (13). Retrieved from: http://www.ijhssnet.com/journals/Vol_3_No_13_July_2013/8.pdf

Mulwa, A., Kyalo, N., Bowa, O., \& Mboroki, G. (2012). Influence of ICT infrastructure on readiness to adopt elearning in secondary schools in Kitui District, Kenya. Journal of Continuing, Open and Distance Education of the University of Nairobi, 2(1).Retrieve from: https://distanceeducation.uonbi.ac.ke/index.php/node/103

Muriuki, K.M. (2017, February 9). Government starts investigations into theft of 46 tablets. Daily Nation. 
Retrieved

http://www.nation.co.ke/news/education/Theft\%20of\%20computers\%20interrupts\%20learning\%20$\% 20$ Daily $\% 20$

National Centre for Education Statistics. (1998). Internet Access in Public Schools. Washington, DC: US Department of Education.

Omanga, D. (2018, February 24). Is Jubilee's laptop project headed for a collapse? Standard Digital. Retrieved from: https://www.standardmedia.co.ke/article/2001270947/jubilee-s-laptop-pledge-doomed-from-the-start

Plessis, A., \& Webb,P. (2012). Teachers' perceptions about their own and their schools' readiness for computer implementation: A South African case study. The Turkish Online Journal of Educational Technology, 11 (3), 312-325.

Reif, L. (2005). Approaches for sustainable e-learning in Africa in German Development Cooperation. Retrieved from:www.hoffmannreif.com/e3091/e146/e4436/.../Sustainable_eLearn ng_in_Africa.pdf

Republic of Kenya. (2015). Digital Literacy Program [press release]. Retrieved from: Information, Communication and Technology Authority of Kenya website : http://www.icta.go.ke/downloads/digital_literacy_program_launch.pdf

Salehi, H \& Salehi, Z. (2012). Challenges for using ICT in education: Teachers'insights. International Journal of e-Education, e-Business, e-Management and e-Learning, 2(1). Retrieve from: http://ijeeee.org/Papers/078Z00061F10037.pdf

Sharples, T., \& Moldéus, K. (2014). Ready or not, here ICT comes: A case study on e-readiness and governance in Kenya's laptop computers project (Unpublished masters dissertation). Retrieved from: http://lup.lub.lu.se/luur/download?func $=$ downloadFile\&recordOId $=4446302 \&$ fileOId $=4643585$

Singh, K. Y. (2010). Research methodology. New Delhi: A. P. H Publishing Corporation

Shimasaki, N. (2015). Integrating ICT into classroom pedagogies: An overview of barriers within the modern classroom. Journal of Initial Teacher Inquiry, 1 (28). Retrieved from: https://core.ac.uk/download/pdf/35473098.pdf

Standard Team. (2019, March 3). Elusive dream: Tablets gather dust in stores as project stalls. Standard Digital. Retrieved from: https://www.standardmedia.co.ke/article/2001315065/tablets-gather-dust-in-stores-asproject-stalls

Tolmie, A., Muijs, D., \& McAteer, E. (2011). Quantitative methods in educational and social research using SPSS. Berkshire. UK: Open University Press.

UNESCO, (2009). Perspectives of Distance Education. Vancouver: Commonwealth of Learning: Retrieve from: $\mathrm{http} / / /$ citeseerx.ist.psu.edu/viewdoc/download?doi=10.1.1.424.8152\&rep=rep1\&type=pdf

UNESCO Institute for Statistics. (2015). Information and communications technology (ICT) in Education in Africa. Retrieved from UNESCO website : http:/uis.unesco.org/sites/default/files/documents/informationand-communication-technology-ict-in-education-in-sub-saharan-africa-2015-en.pdf

Wanzala,O., \& Nyamai, F.(2018, July 23). Big hurdles thwart Jubilee's laptops plan. Daily Nation. Retrieved from: $\quad$ https://www.nation.co.ke/news/Big-hurdles-thwart-Jubilee-s-laptops-plan/1056-46763329w2jndz/index.html 